International Research Journal of Management, IT \& Social Sciences
Available online at https://sloap.org/journals/index.php/irjmis/
Vol. 6 No. 4, July 2019, pages: $1 \sim 7$
ISSN: 2395-7492
https://doi.org/10.21744/irjmis.v6n4.631

\title{
Resistance of Traditional Storage Traders in Encounter Mini- market Competitors in Denpasar City
}

\begin{tabular}{|c|c|}
\hline & $\begin{array}{l}\text { Made Ayunia Kesuma } \\
\text { Nyoman Djinar Setiawina }\end{array}$ \\
\hline Article history: & Abstract \\
\hline $\begin{array}{l}\text { Received: } 27 \text { March } 2019 \\
\text { Accepted: } 31 \text { May } 2019 \\
\text { Published: } 7 \text { June } 2019\end{array}$ & $\begin{array}{l}\text { The results showed that the business location, working hours and a positive } \\
\text { and significant effect on the income of traditional shop vendors in the city of } \\
\text { Denpasar. The price of goods and distance has a negative and significant effect } \\
\text { on the income of traditional traders in Denpasar City. Business capital and } \\
\text { labor have a negative and insignificant effect on the income of traditional } \\
\text { traders in Denpasar City. Business capital and income have a positive and }\end{array}$ \\
\hline $\begin{array}{l}\text { Keywords: } \\
\text { business; } \\
\text { income; } \\
\text { minimarket; } \\
\text { resilience; } \\
\text { traditional shop traders; }\end{array}$ & $\begin{array}{l}\text { significant effect on the resilience of traditional shop vendors in the city of } \\
\text { Denpasar. Business location, distance, and working hours have an indirect } \\
\text { effect on the resilience of traditional shop vendors through income. The price } \\
\text { of goods and capital directly effect the resilience of traditional shop vendors in } \\
\text { the city of Denpasar. The weakness of traditional shop vendors in the city of } \\
\text { Denpasar from the arrangement and shape of the stalls is less neat and the lack } \\
\text { of hospitality of traders, while the strength is that buyers can owe in the stalls. } \\
\text { Opportunities for traditional traders in Denpasar can offer lower prices than } \\
\text { Minimarkets. }\end{array}$ \\
\hline
\end{tabular}

\section{Author correspondence:}

Made Ayunia Kesuma,

Faculty of Economics and Business Udayana University, Bali, Indonesia.

Jalan P.B. Sudirman, Dangin Puri Kelod, Denpasar, Bali 80234

Email address: madenia73@gmail.com

\section{Introduction}

Currently, the modern retail / retail trade which includes Hypermarkets, Supermarkets, Minimarkets and Minimart as an alternative place to shop is increasingly mushrooming in almost all cities in Indonesia, including in Bali. This condition is enough to take a traditional retail / retail place that includes markets, shops, and stalls. The shift in lifestyles due to modernization and globalization makes some consumers more interested in buying in modern retail than traditional retail. Traditional markets are places where sellers and buyers meet and are marked by transactions of sellers and buyers directly. Modern markets are different from traditional markets, in modern markets sellers and buyers do

\footnotetext{
${ }^{\text {a }}$ Faculty of Economics and Business, Udayana University, Denpasar, Indonesia ${ }^{\mathrm{b}}$ Faculty of Economics and Business, Udayana University, Denpasar, Indonesia
} 
not transact directly. The buyer sees the price on the label listed in the item (barcode), is in the building and the service is self-service independently or served by a sales clerk. The emergence of modern markets, especially Minimarkets in Indonesia, will eventually shift traditional stores, this occurs because of the pattern of consumers in shopping and needs to realize that every consumer has different needs. Such restrictions seem to be ignored by modern shopkeepers, so the culmination is the establishment of a modern shop that is uncontrolled and threatens the surrounding economy the impact of the emergence of Minimarkets on each network system and the proximity of the Minimarket to traditional shop effects the income of traditional stall owners. the traditional shops above are considered to be contrary to the Republic of Indonesia's Presidential Regulation No. 112 of 2007 "Regarding the Arrangement and Development of Traditional Markets, Shopping Centers and Modern Stores" In Article 4 paragraph 1 (a) it is stated that modern stores must take into account the socio-economic conditions of the community, the existence of traditional markets, small businesses and medium-sized businesses in the region concerned, the implementation of the above regulations has been carried out by the entrepreneurs at the time of the establishment of the Minimarket (Singapurwa et al., 2017; Gama et al., 2018).

The most Minimarket deployment areas are in South Denpasar, along with the population spread in South Denpasar as many as 83,027 people, besides that the position of Minimarkets is also close to tourist areas and quite densely populated residential areas. Minimarket spread figures amount to 123 units of various types of Minimarkets in South Denpasar, so it is only natural that this area is the most densely populated Minimarket spread in Denpasar, Minimarket Hypermarkets and Supermarkets, especially in big cities because they offer more choices than temporary Minimarkets. the prices offered by Hypermarkets and Supermarkets are relatively the same even in some items it can be cheaper than Supermarkets). However, Hypermarket and Supermarket formats are not very favorable (Genggong \& Ashmarita, 2018).

\section{Literature Review}

\section{Strategies That Traditional Stall Traders to Face Competition with Minimarkets}

Zambrano et al., (2019), the marketing strategy that is determined must be reviewed and developed in accordance with market developments in the market environment, thus, the marketing strategy must be able to provide a clear and directed picture of what the company will do in using every opportunity or opportunity in several target markets. Traders in traditional markets must develop strategies and develop plans that are able to meet the needs and demands of consumers as modern markets do. It is undeniable that the presence of a modern market near a traditional market will certainly increase trade competition, both between modern markets and traditional markets, traditional versus modern in the trade business, becoming a phenomenon that traditional market managers must observe before leaving or implementing it as a business strategy when traditionalism began to be abandoned by traditional market traders.

\section{Differences between Traditional Markets and Modern Retail}

Economic development that occurs causes competition to occur between traditional economic activities with modern economic activities. These two things are inseparable always running side by side as happened in traditional markets facing modern retail competition. This phenomenon is confirmed by the theory of Dualism which was first coined by J. Boeke in his book entitled Economics and Economic Policy in Dual Societies, 1953. According to Boeke said that in a society there might be two different systems. Both forms coexist in which one cannot fully master the other (Pardiana, 2011).

\section{Competition between Traditional Markets and Modern Retail}

With the rapid growth in the number of modern retailers, competition in the trade sector is getting tougher. For traders who are not ready to face the incessant entry of new traders that are more attractive by using various attractive marketing strategies and accompanied by modern technology coupled with better management, the competition will be even tighter (Gorda et al., 2018). 


\section{Strategies in Business Competition}

Small companies and companies that want to improve efficiency, can market segmentation, they can focus marketing activities on selected market segments if the market target has been determined through marketing research, the company must make a good plan to enter the chosen market segment (Nuryani et al., 2018).

\section{Conceptual Framework}

In this model it is explained that rapid economic development, makes the trade sector more advanced, this can be seen by the number of emerging modern shops around residential areas such as Minimarkets and Supermarkets which have almost rivaled many grocery / traditional stalls around the population area and competition between traditional Minimarkets and shops, so that stall owner is not left behind by their consumers so they must look at the conditions from the external and internal aspects so they can compete with the Minimarket. The location of the adjacent shop business from the population area is considered to be easier to reach by consumers, the distance between the establishment of Minimarket and the traditional shop on the income obtained by traditional shop owners, so that the income of the merchants obtained changes (Pattiasina et al., 2019).

\section{Hypothesis}

1) Business capital, distance, working hours have a positive and significant effect on Shop's income.

2) The location of the business near the settlement is higher than the non-residential business location.

3) The price of goods in the shop is higher than the Minimarket

4) Business capital, distance, working hours and income have a positive and significant effect on the durability of Shop traders.

5) The location of the business near the settlement is higher than the non-residential business location.

6) Prices of goods installs have a higher resistance compared to Minimarkets.

There is an indirect effect of business capital, distance, working hours, on the resilience of shop vendors through the income of traditional shops in Denpasar City.

\section{Materials and Methods}

In this study, the purpose of the population is all traditional stalls in South Denpasar in 4 villages in 5 villages. Following are the Trader and Minimarket Populations by region, the population used for traditional shops is 177 traditional shops in Denpasar City. Analysis of research data using path or path analysis and Sobel test To test the significance of indirect effects, we need to calculate the value of $t$ from the $a b$ coefficient with the formula $\mathrm{z}=\mathrm{ab}$ to determine the decision-making hypothesis test, done by comparing the value of $t$ table with $t$ count. If the value of $t$ count is greater than the value of $t$ table, it can be concluded that there is a mediating effect. Path analysis is an examination of validity or the truth of the model of whether or not the results of analysis depend on whether or not the underlying assumptions are met.

\section{Results and Discussions}

\subsection{Linear}

Table 1

Regression testing result

\begin{tabular}{llll}
\hline Correlation & R-Square & F & Sig. \\
\hline X1 -> Y1 & 0,048 & 4,989 & 0,028 \\
X2 -> Y1 & 0,430 & 73,823 & 0,000 \\
X3 -> Y1 & 0,194 & 23,540 & 0,006 \\
\hline
\end{tabular}

Kesuma, M. A., \& Setiawina, N. D. (2019). Resistance of traditional storage traders in encounter mini-market competitors in Denpasar city. International Research Journal of Management, IT and Social Sciences, 6(4), 1-7. https://doi.org/10.21744/irjmis.v6n4.631 


\begin{tabular}{llll}
\hline $\mathrm{X} 4$-> Y1 & 0,067 & 7,061 & 0,009 \\
$\mathrm{X} 5$-> Y1 & 0,178 & 21,242 & 0,000 \\
$\mathrm{X} 1$-> Y2 & 0,007 & 0,727 & 0,396 \\
$\mathrm{X} 2$-> Y2 & 0,332 & 40,735 & 0,000 \\
$\mathrm{X} 3$-> Y2 & 0,198 & 24,190 & 0,000 \\
$\mathrm{X} 4$-> Y2 & 0,127 & 14,220 & 0,000 \\
$\mathrm{X} 5$-> Y2 & 0,041 & 4,168 & 0,044 \\
$\mathrm{Y} 1$-> Y2 & 0,693 & 220,781 & 0,000 \\
\hline
\end{tabular}

Primary Data, 2018

Based on Table 1 it can be seen that there are two variables that are not linearly related to each other, namely the relationship between variables X1 -> Y2 and X6 -> Y2. This result is indicated by a significance greater than 0.05 . The relationship between other variables shows a linear relationship seen from a significance value of less than 0.05 . The most linear relationship is between Y1 -> Y2, which is indicated by the largest F-Count, which is equal to 220.781 .

\subsection{Validity Model Evaluation}

Table 2

Validity Model Evaluation

\begin{tabular}{llll}
\hline Dependent & Independent & $\mathrm{R}^{2}$ & Description \\
\hline Y1 & $\mathrm{X} 1, \mathrm{X} 2, \mathrm{X} 3$, & 0,599 & Strong \\
& $\mathrm{X} 4, \mathrm{X} 5$ & & \\
$\mathrm{Y} 2$ & $\mathrm{X} 1, \mathrm{X} 2, \mathrm{X} 3$, & 0,777 & Strong \\
& $\mathrm{X} 4, \mathrm{X} 5, \mathrm{Y} 1$ & & \\
\hline
\end{tabular}

Primary Data, 2018

In this study there are two dependent variables, namely stall income (Y1) and stall resistance (Y2). Against the two dependent variables, the independent variable gives the value Y1 giving a value of 0.599 so that the independent variable on the dependent variable is classified as strong. While the income level variable (Y2) gives a value of 0.777 so that the independent variables on the dependent variable are also classified as strong.

\subsection{Direct Effect}

Table 3

Path Coefficient

\begin{tabular}{lllll}
\hline Correlation & Std. Coefficient & Standard Error & P-value & Description \\
\hline X1 -> Y1 & 0,137 & 0,048 & 0,048 & Sig. \\
X2 -> Y1 & $-0,590$ & 0,061 & 0,000 & Sig. \\
X3 -> Y1 & 0,050 & 0,004 & 0,669 & No sig. \\
X4 -> Y1 & $-0,250$ & 0,000 & 0,000 & Sig. \\
X5 -> Y1 & 0,273 & 0,016 & 0,000 & Sig. \\
X1 -> Y2 & $-0,131$ & 0,083 & 0,014 & Sig. \\
X2 -> Y2 & 0,013 & 0,123 & 0,874 & No sig. \\
X3 -> Y2 & 0,249 & 0,006 & 0,005 & Sig. \\
X4 -> Y2 & $-0,162$ & 0,000 & 0,003 & Sig. \\
X5 -> Y2 & $-0,155$ & 0,029 & 0,006 & Sig. \\
Y1 -> Y2 & 0,813 & 0,175 & 0,000 & Sig. \\
\hline
\end{tabular}

Primary Data, 2018

Information:

$\mathrm{X} 1$ is the business location

$\mathrm{X} 2$ is the price of goods 
$\mathrm{X} 3$ is business capital

$\mathrm{X} 4$ is distance

$\mathrm{X} 5$ is working hours

$\mathrm{X} 6$ is the number of workers

$\mathrm{Y} 1$ is income

$\mathrm{Y} 2$ is endurance

\subsection{Indirect Effect}

If $\mathrm{z}$ value in absolute price $>\mathrm{z}$ - table equals 1.960 at $\alpha=0.05$, it means that the stall income variable is a mediating variable. The business location does not directly affect the resilience of the merchant shop, this can be seen from the value of $\mathrm{z}$ calculating the business location variable $(|2,000|)$ greater than $\mathrm{z}$ table. The variable price of goods also does not directly affect the resilience of traditional shop vendors, this can be seen from z count (| -6,294 |) which is greater than $\mathrm{z}$ table. Distance and working hours also do not directly affect the resilience of shop traders because the value of $z$ count distance $(|-3,800|)$ and the value of $z$ count of working hours are $(|3.875|)$ which is greater than $z$ table. However, income is not a variable that mediates the effect of the variables of business capital and working hours on the durability of stall traders. It can be seen from $\mathrm{z}$ calculating business capital and working hours smaller than $\mathrm{z}$ table.

\subsection{The Effect of Business Location, Price of Goods, Business Capital, Distance, Working Hours, and Labor Against the Income of Traditional Shop Traders in Denpasar City}

Based on the results of the analysis, the business location variable has a positive and significant effect with a coefficient of 0.048 on the income of traditional merchant stalls in Denpasar, which means that the research hypothesis is accepted. The closer the business location is too densely populated settlements, the higher the level of income generated by the merchant shop. Based on the results of the study of Goods Prices Negative and significant effect with the coefficient -0.384 on the income of merchant stalls in the city of Denpasar, this means that the research hypothesis was rejected because of its negative direction. This means that the higher the price of goods, the higher the income, consumers will tend to look for goods or services whose prices are relatively cheaper to be used as an alternative for purchasing decisions. Business capital is not significant to the income of merchant stalls in the city of Denpasar, with a coefficient of 0.669 , this means that the hypothesis is rejected, which means that business capital decreases, the income will increase. The results show that stall business capital does not affect its income. Distance has a significant negative effect on the income of merchant stalls in Denpasar City with this means the hypothesis is rejected. With a significance of 0,000 , the closer the distance between the shop and the Minimarket, the higher the income, the distance between the merchant shop and the Minimarket is measured in meters. Working hours have a positive and significant effect on the income of traditional traders in Denpasar, which means that the research hypothesis is accepted. With a significance of 0,000 which means if the number of long working hours will make the work more productive, and by working productively it is expected to generate good income. The stall income has a positive and significant effect on the resilience of Traditional stall traders in Denpasar City whose significance is 0,000 . then if income increases then profits will increase Revenue is the company's top priority in running its business where if the income is large then the company's profits will be large too but if the income is small then the profits will be small too, in this study income effects business profits which means rising income is accompanied by an increase in the profits of the stall business.

\subsection{Indirect Effects of Business Location, Price of Goods, Business Capital, Distance, Hours of Work and Manpower Against Resilience of Traders of Commercial Stalls Through Income of Traditional Stall Traders in the City of Denpasar}

Business location directly effects the resilience of traditional shop traders with a coefficient of 0.024 to the level of income. The location starts with choosing a community this decision is very dependent on the potential for economic growth and stability of competition, climate, politics and so on. The price of goods for the resilience of merchant stalls in Denpasar City. This means that the price of goods has an indirect effect on the durability of shop traders with a coefficient of -0.103. Tight competition, low and high economic growth and business opportunities for those who keep the market. Effect of Business Capital directly effects the Resilience of traditional stalls in the city of Denpasar with a coefficient of 0.009. If a business capital used is not well developed, such as buying too much merchandise and

Kesuma, M. A., \& Setiawina, N. D. (2019). Resistance of traditional storage traders in encounter mini-market competitors in Denpasar city. International Research Journal of Management, IT and Social Sciences, 6(4), 1-7. https://doi.org/10.21744/irjmis.v6n4.631 
eventually not selling it on the market, it will have an impact on profits received so that a stalled business cannot last long in market competition. Distance has a direct effect on the resilience of merchant stalls in Denpasar City with a coefficient of 0.044 if there is a distance between one trader and another trader where time and cost are needed. Working hours directly effect the resilience of shop vendors in the city of Denpasar with a coefficient of 0.048 hours of work undertaken by traders, the higher the income earned, in addition to capital and labor factors the level of profit of traders is also determined by the length of operation or working hours.

\section{Conclusion}

The effect of the shifting of traditional merchant stalls against Minimarkets that are increasingly developing in the Denpasar City area by analyzing several business location factors, business capital, price of goods, distance and application of working hours in traditional stalls which are deemed to still need development with Minimarkets such as cooperating with larger grocery stalls to be able to supply goods needed by consumers every day. Socialization from the government is also needed to maintain the existence of shop merchants so as not to reduce their economic welfare. For stall traders, they are expected to be able to arrange new strategies to overcome competition, traders should have developed their businesses to achieve more income by revamping stalls so that buyers are more comfortable and interested in shopping installs, and conducting administrative books so that financial expenses and profits are more clear. The owners of traditional stalls are expected not to make modern shopkeepers an enemy in business, but traditional stall owners are expected to follow the strategy of the modern market so that they are able to compete in the market.

\section{Limitations Research}

This study analyzes traders of traditional stalls in Denpasar City against the presence of modern markets. Shop traders are sampled in this study, selecting respondents by choosing a shop merchant whose place is close to the Minimarket.

\section{Conflict of interest statement and funding sources}

The authors declared that they have no competing interest.

\section{Statement of authorship}

The authors have a responsibility for the conception and design of the study. The authors have approved the final article.

\section{Acknowledgments}

The authors would like to thank the Editor of IRJMIS for their valuable time, support, and advice in completing the current study. 


\section{References}

Gama, A. W. S., Rustiarini, N. W., \& Anggraini, N. P. N. (2018). Imaging and Purchasing Decision in Traditional Art Market. International Research Journal of Management, IT and Social Sciences, 5(2), 175-185.

Genggong, M. S., \& Ashmarita, -. (2018). Government role in development of child-friendly city based on traditional games. International Research Journal of Management, IT and Social Sciences, 5(4), 53-60. https://doi.org/10.21744/irjmis.v5n4.260

Gorda, A. O. S., Romayanti, K. N., \& Anggreswari, N. P. Y. (2018). Social capital, spiritual capital, human capital, and financial capital in the management of child welfare institutions. International Journal of Social Sciences and Humanities, 2(3), 12-20. https://doi.org/10.29332/ijssh.v2n3.183

Nuryani, N. N. J., Satrawan, D. P. R., Gorda, A. A. N. O. S., \& Martini, L. K. B. (2018). Influence of human capital, social capital, economic capital towards financial performance \& corporate social responsibility. International Journal of Social Sciences and Humanities, 2(2), 65-76. https://doi.org/10.29332/ijssh.v2n2.128

Pattiasina, V., Tammubua, M. H., Numberi, A., Patiran, A., \& Temalagi, S. (2019). Capital Intensity and tax avoidance. International Journal of Social Sciences and Humanities, 3(1), 58-71. https://doi.org/10.29332/ijssh.v3n1.250

Singapurwa, N. M. A. S., Semariyani, A. M., \& Candra, I. P. (2017). Identification of implementation of GMP and SSOP on processing of balinese traditional food sardine pedetan. International Research Journal of Engineering, IT \& Scientific Research, 3(3), 20-30.

Wijayanti, P., \& Wiratno, W. (2011). Analisis Pengaruh Perubahan Keuntungan Usaha Warung Tradisional Dengan Munculnya Minimarket (Studi Kasus Di Kecamatan Pedurungan Kota Semarang) (Doctoral dissertation, Universitas Diponegoro).

Zambrano, T. Y. M., Castro, I. C. G., Plaza, C. L. M., \& Farfan, R. M. (2019). Recovery of ancestral knowledge for production of traditional Manabí cocoa paste. International Journal of Life Sciences, 3(1), 71-78. https://doi.org/10.29332/ijls.v3n1.274

Kesuma, M. A., \& Setiawina, N. D. (2019). Resistance of traditional storage traders in encounter mini-market competitors in Denpasar city. International Research Journal of Management, IT and Social Sciences, 6(4), 1-7. https://doi.org/10.21744/irjmis.v6n4.631 